\title{
China-Rare Earths: Export Restrictions and the Limits of Textual Interpretation
}

\author{
ERIC W. BOND* \\ Vanderbilt University \\ JOEL TRACHTMAN ** \\ The Fletcher School of Law and Diplomacy, Tufts University
}

\begin{abstract}
The China-Rare Earths decision of the Appellate Body addressed two main issues: (i) whether China's obligations not to impose export duties under its accession protocol are subject to exceptions under Article XX of GATT, and (ii) the scope of the exception for China's export quota measures relating to conservation under Article XX(g) of GATT. In accord with its China-Raw Materials decision, the Appellate Body found that there is no textual basis for the application of the Article XX exception to China's export duty obligations. This interpretation exalted a narrow contextual approach over an approach to interpretation that would focus on broader context, object, and purpose. The Appellate Body also approved the Panel's overall approach to determining the availability of the Article XX $(\mathrm{g})$ exception. This approach focused on the design and structure of China's quota measure, but left unresolved important issues, including the extent to which non-conservation purposes may prevent use of the exception and the role of empirical evidence of effects in these determinations. While the Appellate Body found that there is no 'even-handedness' requirement in Article XX(g) itself, we argue that the chapeau's requirement of nondiscrimination is an appropriate additional criterion for determining whether a policy with a target of reducing extraction of a natural resource satisfies the requirements of Article XX.
\end{abstract}

\section{Introduction: major economic and legal issues}

This Appellate Body decision ${ }^{1}$ arose from complaints by the United States, the European Union, and Japan against China's export duties and export quotas on rare earths, tungsten, and molybdenum.

\footnotetext{
*Email: eric.w.bond@vanderbilt.edu

** Email: joel.trachtman@tufts.edu

1 Appellate Body Report, China-Measures Related to the Exportation of Rare Earths, Tungsten, and Molybdenum, WT/DS431,432,433/AB/R, adopted 29 August 2014 (hereinafter Rare Earths Appellate Body Reports).
} 
The complainants requested the Panel to find that the relevant export duties were inconsistent with Paragraph 11.3 of China's Accession Protocol (the 'CAP'), which states that 'China shall eliminate all taxes and charges applied to exports unless specifically provided for in Annex 6 of this Protocol or applied in conformity with the provisions of Article VIII of the GATT 1994'. The relevant export duties were not specifically provided for in Annex 6. Notably, the General Agreement on Tariffs and Trade (GATT 1994) generally does not restrict export duties, so this is a GATT-plus obligation.

The complainants also requested the Panel to find that the relevant export quotas violate Article XI:1 of GATT 1994.

China conceded and the Panel found that China's export duties and quotas violated these provisions, but China sought to defend them under Article XX(b) and XX $(\mathrm{g})$ of GATT 1994, respectively. ${ }^{2}$ While it is clear that Article XX of GATT 1994 applies to provide exceptions with respect to violations of Article XI of GATT by virtue of China's export quotas, one of the issues in this case was the applicability of Article XX to China's GATT-plus obligation to eliminate export duties under the CAP. The Panel considered whether the obligation in Paragraph 11.3 of the CAP is subject to the general exceptions contained in Article XX, and, even though a majority of the Panel found that it is not, the Panel also considered the hypothetical application of Article $\mathrm{XX}(\mathrm{b})$ to China's violation of Paragraph 11.3. However, the Panel found that the Panel in China-Rare Earths 'failed to demonstrate that its export duties are designed and structured to protect human, animal or plant life or health' (para. 7.171).

This case was preceded by the Appellate Body's decision in China-Raw Materials (Bronckers and Maskus, 2014; Qin, 2012), ${ }^{3}$ which also considered the question of the availability of the general exceptions contained in Article XX in connection with Paragraph 11.3 of the CAP. In China-Rare Earths, China did not appeal the Panel's finding that Article XX does not apply to its export duty obligations, but instead limited its appeal to some of the Panel's related reasoning.

\section{Background and facts}

This case addressed claims against China's export duties and export restrictions on rare earths, tungsten, and molybdenum. 'Rare earths' includes a group of 17 elements with the special properties of magnetism, luminescence, and strength,

2 It appears that China chose to defend its export duties under Article $\mathrm{XX}(\mathrm{b})$ because, for the export duties, there was no domestic restriction as required for the defense under Article XX(g). Panel Report, China-Measures Related to the Exportation of Rare Earths, Tungsten and Molybdenum, WT/ DS431,432,433/R, 13 December 2013, paras. 7.172-179 (hereinafter Rare Earths Panel Reports).

3 Appellate Body Reports, China-Measures Related to the Exportation of Various Raw Materials, WT/DS394/AB/R, WT/DS395/AB/R, WT/DS398/AB/R, adopted 22 February 2012 (hereinafter Raw Materials Appellate Body Reports). 
important in the production of high-tech products, including weapons systems and clean energy products. China is the dominant producer of rare earths, providing approximately $97 \%$ of the world supply (Morrison and Tang, 2012). 'Rare earth deposits often contain radioactive elements, which means separating the metals requires costly and strenuous processes that produce a number of toxic pollutants and hazardous waste material' (Morrison and Tang, 2012). In other words, rare earth production causes serious production externalities.

Between 2005 and 2010, Chinese export quotas in rare earths were cut by more than $50 \%$, resulting in a more than a seven-fold increase in world prices. In light of the importance of these products for national security and environmental applications, these price increases generated substantial public concern in the US, Japan, and European Union. In the US, 14 bills were introduced in the US Congress to address the availability of rare earths.

\section{Relation of China Accession Protocol (CAP) to GATT Art. XX}

The first substantive legal issue addressed at the Panel level was the question of whether Article 11.3 of the CAP, the provision prohibiting the relevant export duties, is subject to defenses under Article XX of GATT. Article XX of GATT, by its terms, provides that 'nothing in this Agreement shall be construed to prevent the adoption or enforcement by any contracting party of [listed] measures' (emphasis added). So, in order for the CAP obligation to be eligible for an Article $\mathrm{XX}$ defense, the relevant provisions of the CAP must somehow be included in 'this Agreement' - in the GATT - or the Article XX exceptions must be incorporated by reference in the CAP. However, the obligations in Article 11.3 are GATT-plus obligations, which do not textually form part of 'this Agreement' as referenced in the chapeau of Article XX. Nor is there a plausible textual basis for arguing that the Article XX exceptions are incorporated by reference.

\subsection{The Raw Materials Appellate Body Report and the role of precedent}

The issue of availability of Article XX of GATT 1994 was not new. In an earlier, and similar case, China-Raw Materials, the EU, Mexico, and the US successfully challenged China's restrictions on exports of certain 'raw materials' - bauxite, coke, fluorspar, magnesium, manganese, silicon carbide, silicon metal, yellow phosphorus, and zinc. In that case, the Appellate Body upheld the Panel's determination and held that 'a proper interpretation of Paragraph 11.3 of China's Accession Protocol does not make available to China the exceptions under Article XX of the GATT 1994' (para. 307).

While there is no formal doctrine of binding precedent in WTO jurisprudence, the Appellate Body tends to insist on Panels following its earlier decisions, and Panels tend to do so. In addition, the Appellate Body seeks to maintain consistency among its decisions across time. In the present case, however, China asserted 'new 
arguments that have not been asserted previously, or arguments which were neither argued nor addressed fully by the Panel and the Appellate Body in China-Raw Materials'. ${ }^{4}$ Referring to the Appellate Body report in US-Stainless Steel (Mexico), where the Appellate Body stated that 'absent cogent reasons, an adjudicatory body will resolve the same legal question in the same way in a subsequent case', ${ }^{5}$ China argued that there were 'cogent reasons' here.

\subsection{A contrario arguments and textualism}

The issue of the role of Article XX in connection with the CAP has been troublesome in several contexts. In China-Publications, the Appellate Body agreed with China's argument that the introductory clause of paragraph 5.1 of the CAP which reads, 'Without prejudice to China's right to regulate trade in a manner consistent with the WTO Agreement' - implicitly incorporates by reference Article XX of GATT. ${ }^{6}$ According to the Appellate Body's determination in China-Raw Materials that incorporation is only for the purpose of Article 5.1, and serves as a contrario evidence that a similar limitation does not also apply where it is not expressed, as in Article 11.3 of the CAP. ${ }^{7}$ Furthermore, in the China-Raw Materials case, the Appellate Body drew an a contrario inference from the references to GATT 1994 in Articles 11.1 and 11.2 of the CAP. ${ }^{8}$

This type of a contrario argument can easily be reversed (Trachtman 2013): if the limitation makes sense in Article 5.1, or in Articles 11.1 and 11.2, of course it also makes substantive sense in Article 11.3. However, the latter approach assumes a certain level of incompetence, or at least inconsistency, on the part of the drafters, and the WTO dispute settlement process has generally declined to assume incompetence or inconsistency. Rather, it uses an effet utile 9 approach to give meaning to differences in expression across different provisions of WTO law.

However, there is a normatively appealing non-textual basis for applying the Article XX exceptions to China's CAP Article 11.3 obligations, and it is the same normative basis as that which must have motivated the inclusion of Article $\mathrm{XX}$ in the original GATT: states expected to encounter circumstances in which

4 Rare Earths, First Written Submission of China, paras. 416 and 460.

5 Appellate Body Report, United States-Final Anti-Dumping Measures on Stainless Steel from Mexico, WT/DS344/AB/R, adopted 20 May 2008, paras. 160-162.

6 Appellate Body Report, China-Measures Affecting Trading Rights and Distribution Services for Certain Publications and Audiovisual Entertainment Products, WT/DS363/AB/R, adopted 19 January 2010 (hereinafter China-Publications).

7 Raw Materials Appellate Body Reports, para. 291.

8 In this context, an a contrario argument suggests that if a rule or qualification is stated in one place, and not stated in another place within the same agreement or statute, it is inappropriate to infer the rule or qualification in the latter place. It recognizes that positive statements can serve as the basis for negative inferences.

9 Effet utile is the interpretive principle that each term in a treaty, and each difference in expression, is to be given meaning, and not reduced to 'inutility'. 
their GATT/WTO obligations should yield to other policy goals, and Article XX is the major basis, in connection with trade in goods, for distinguishing between acceptable and unacceptable claims for exception. Evidence of the desire to achieve this balance between trade and the 'right to regulate' can be found in the context, object, and purpose of the WTO Agreements. In the China-Raw Materials dispute, the Appellate Body held that 'we understand the WTO Agreement, as a whole, to reflect the balance struck by WTO Members between trade and non-trade-related concerns' (para. 306).

Under Article 31 of the Vienna Convention on the Law of Treaties (VCLT), treaties are to be interpreted according to the ordinary meaning of their terms in context and in light of the treaty's object and purpose. According to the ordinary meaning of the word 'comprise' in Article 31 itself, interpreted using the expressio unius principle of interpretation, ${ }^{10}$ 'context' is limited to the text, including preambular language and annexes, as well as agreements and instruments made or accepted by all the parties in connection with the conclusion of the treaty. It is uncertain whether the authors of the VCLT intended to exclude other elements. ${ }^{11}$ However, there is ample preambular language, for example in the first preamble of the Marrakesh Agreement Establishing the World Trade Organization, to support the desire to balance trade and non-trade concerns.

While it is difficult to separate text from context, the Appellate Body has generally given priority to text and to a narrow type of context, focusing on comparing words used in different provisions and to giving effet utile to differences, as compared to object and purpose, and as compared to a broader sense of context. In this case, the result is a restriction of the right to regulate that is difficult to justify in substantive terms. For example, no one has proposed a policy-based explanation for why export duties would be ineligible for an Article XX exception while export quotas can take advantage of Article XX.

In China-Raw Materials, China rejected 'the view that China has not only assumed uniquely onerous obligations regarding export duties on goods, but that it has also abandoned its right to use export duties under exceptional circumstances to promote fundamental non-trade interests explicitly recognized by the WTO Agreement'. ${ }^{12}$ In China-Rare Earths, China emphasized that it 'finds repugnant the argument that it has not only assumed uniquely onerous obligations, but also that it is denied its "inherent power" to take measures in relation to these uniquely onerous obligations to promote other fundamental interests, such as conservation and public health'. ${ }^{13}$

10 Expressio unius is a canon of interpretation that infers that the express mention of particular items is intended to exclude other items of that type.

11 For an argument that they did not, see Isabelle Van Damme (2009).

12 First Written Submission of China, para. 459.

13 Raw Materials Panel Reports, Annex D-2, p. D-17, para. 24. 
As the Panel in the present case recounted, 'in China-Raw Materials, the Appellate Body concluded that the WTO Agreement "reflect[s] the balance struck by WTO Members between trade and non-trade-related concerns", but that "none of the objectives [contained in WTO agreement preambles], nor the balance struck between them, provides specific guidance" on the question of whether Article XX of the GATT 1994 is applicable to Paragraph 11.3 of China's Accession Protocol'. ${ }^{14}$ It is not specific guidance, but it is important as a source of agreed context, object, and purpose for interpretation. China argued in China-Rare Earths that the Appellate Body's 'summary dismissal of the interpretative value of the WTO's fundamental objectives without any further explanation [in China-Raw Materials] does not rise to the level of a proper objective assessment of legal issues before it'. ${ }^{15}$ It is a rather limited approach to interpretation.

The Panel in Rare Earths seemed to come close to agreeing with China, stating that in sum, the Panel agrees with China that an interpretation of the covered agreements that resulted in sovereign States being legally prevented from taking measures that are necessary to protect the environment or human, animal or plant life or health would likely be inconsistent with the object and purpose of the WTO Agreement' (para. 7.114). It did not explain how it determined that the text-based aspect of the interpretation that it followed supervenes the agreement's broader context, object, and purpose. But it pointed out, apparently as consolation, that, under the Panel's interpretation, China foregoes only one policy instrument for use in carrying out the 'right to regulate': export duties. (paras. 7.111-7.117). Apparently, the Panel's argument is that China retained sufficient alternatives so that it was not prevented from protecting these values, and so this interpretation is not actually inconsistent with the object and purpose of the WTO Agreement. Here, the Panel uses a very broad understanding of object and purpose, avoiding an interpretation that the object and purpose of the WTO Agreement is, in part, instantiated in Article XX itself.

Why did the Panel then feel that it must prioritize ordinary meaning above broader context, object, and purpose? There are good practical reasons why the Appellate Body has, since the founding of the WTO, focused on text, including the fact that for many sources of object and purpose, 'most treaties have no single, undiluted object and purpose but rather a variety of different, and possibly conflicting, objects and purposes'. ${ }^{16}$ The VCLT does not determine the relative weight of (i) ordinary meaning, (ii) context, or (iii) object and purpose. In international legal adjudication this weighing is implicitly assigned to the judge. It is not clear that the application of the VCLT interpretive rules should vary by context, allowing WTO judges to apply them differently than other judges. Even

14 Ibid., para. 7.71, citing Appellate Body Reports, China-Raw Materials, para. 306.

15 First Written Submission of China, para. 448; Rare Earths Panel Reports, para. 7.110.

16 Appellate Body Report, United States - Import Prohibition of Certain Shrimp and Shrimp Products, WT/DS58/AB/R, adopted 6 November 1998 (hereinafter Shrimp Appellate Body Report), para. 17. 
if they may do so, perhaps the pendulum has swung too far in the direction of a limited textualism divorced from broader context.

\subsection{The meaning of integration}

In China-Rare Earths, China introduced an argument that it asserted had not been raised in China-Raw Materials. China argued that under Article 1.2 of the CAP, the CAP is an 'integral part' of the WTO Agreement. China argued that Article 1.2 makes different parts of the CAP integral parts of the substantively related WTO agreement. According to this argument, the provisions of the CAP that relate, for example, to the TRIPS portion of the WTO Agreement, are an integral part of the TRIPS, while, as salient here, Article 11.3 of the CAP is an integral part of the GATT 1994. ${ }^{17}$ China also referred to Article XII:1 of the Marrakesh Agreement, which provides that a State 'may accede to this Agreement, on terms to be agreed between it and the WTO. Such accession shall apply to this Agreement and the Multilateral Trade Agreements annexed thereto'.

The majority of the Panel found that while the CAP is an integral part of the WTO Agreement, no particular provision of the CAP is an integral part of any particular WTO sub-agreement, such as the GATT 1994 (para. 7.82). The majority of the Panel also found that the integration that China argued for would render specific cross-references - to GATT or to specific provisions of GATT - inutile, and on this basis rejected such integration (paras. 7.86-7.87). This is a typical WTO a contrario interpretative tactic, in which if a term is present in one place, it is assumed that it was not intended to apply in other places.

A dissenting panelist agreed with China to the effect that Article 11.3 of the CAP is an integral part of GATT 1994, and therefore eligible for exceptions under Article XX (paras. 7.3.2.1.8-7.138). Perhaps encouraged by the dissent, China appealed the Panel's rejection of its argument that paragraph 11.3 of the CAP must be treated as an integral part of the GATT 1994. This question turns on an interpretation of Article XII:1 of the Marrakesh Agreement Establishing the World Trade Organization, as well as Article 1.2 of the CAP. Article XII: 1 of the Marrakesh Agreement provides as follows: '[any] accession shall apply to this Agreement and the Multilateral Trade Agreements annexed thereto'.

This language seems intended to ensure that acceding states accept the single undertaking, including all the Multilateral Trade Agreements. ${ }^{18}$ In addition, Article II:2 of the Marrakesh Agreement provides that the Multilateral Trade Agreements are integral parts of the Marrakesh Agreement. It is all one treaty, including the Multilateral Trade Agreements.

On appeal, the Appellate Body rejected China's line of argument, holding that 'Article XII:1 itself does not speak to the question of the specific relationship

17 Rare Earths Panel Reports, para. 7.75.

18 Rare Earths Appellate Body Reports, para. 5.33. 
between individual provisions of an accession protocol and individual provisions of the Marrakesh Agreement and the Multilateral Trade Agreements' (para. 5.34).

China made a similar argument based on Article 1.2 of the CAP, which provides that ' $[t]$ his Protocol, which shall include the commitments referred to in paragraph 342 of the Working Party Report, shall be an integral part of the WTO Agreement'. China's logic was that if 'the WTO Agreement' includes GATT 1994, then the CAP is an integral part of GATT 1994, and thus Article 11.3 of the CAP would be eligible for Article XX exceptions. As noted above, Article II: 2 of the Marrakesh Agreement (the WTO Agreement) provides that the Multilateral Trade Agreements are integral parts of the Marrakesh Agreement. ${ }^{19}$

Article 1.3 of the CAP refers to the WTO Agreement and the Multilateral Trade Agreements separately, and, from this context, the Appellate Body inferred that the reference to the WTO Agreement in Article 1.2 of the CAP includes the WTO Agreement (artificially) separated from the Multilateral Trade Agreements. Thus, the Appellate Body rejected the argument that the CAP is an integral part of the GATT 1994.

The Appellate Body concluded that the term 'WTO Agreement' means different things in different places, but it did 'not consider that determining the scope of the term "the WTO Agreement" in Paragraph 1.2 was dispositive of the key legal question before the Panel; that is, the specific relationship between individual provisions of China's Accession Protocol and the individual provisions of the Marrakesh Agreement and the Multilateral Trade Agreements' (para. 5.49).

Thus, the relationship among different provisions of the broad WTO Agreement depends on the particular context of those provisions. The Appellate Body gave the example of cumulative application of the Safeguards Agreement and Article XIX of GATT $1994,{ }^{20}$ as well as the more salient example of the China-Publications decision, in which it observed that 'whether China may, in the absence of a specific claim of inconsistency with the GATT 1994, justify its measure under Article XX of the GATT 1994 must in each case depend on the relationship between the measure found to be inconsistent with China's trading rights commitments, on the one hand, and China's regulation of trade in goods, on the other hand' ${ }^{21}$

So, given that the integration arguments produced no conclusion, the Appellate Body returned to expressio unius arguments about Article 11.3 of the CAP itself. That is, it referred to the finding of the Appellate Body in China-Raw Materials that the fact that Article 11.3 already states some exceptions to China's export

19 The Marrakesh Agreement and the WTO Agreement are the same thing. Although the Appellate Body, like the Panel in this case, followed the convention of using 'the Marrakesh Agreement' to refer to the Marrakesh Agreement Establishing the World Trade Organization excluding its annexes, this was without prejudice to the question of whether references to the Marrakesh Agreement in the CAP meant such agreement with or without its annexes.

20 Appellate Body Report, Argentina - Safeguard Measures on Imports of Footwear, WT/DS121/AB/ R, adopted 12 January 2000, para. 97.

21 China-Publications Appellate Body Report, para. 229. 
duty elimination obligations indicates that no other exceptions were contemplated. (para. 5.63)

The language that forms the basis for China's integration arguments is not a model of clarity, and China's arguments are at least plausible interpretations. As the Appellate Body recognized, there is a good argument that the text itself is unclear on whether particular provisions of the CAP are 'integral parts' of GATT 1994. Indeed, specific references incorporating GATT 1994 or its provisions in the CAP would have been rendered inutile by a reading that all of the GATT 1994-related provisions of the CAP are already integral parts of GATT 1994. However, there is much in WTO law, and in the CAP, that is inutile. For example, Articles 11.1 and 11.2 of the CAP are both clearly inutile, as they simply call for compliance with GATT 1994 . So avoiding inutility is not a foolproof canon of interpretation.

Under these circumstances of indeterminate text, it might be argued that broader context, object, and purpose would be emphasized as interpretive bases under Article 31 of the VCLT for determining the relationship between Article 11.3 of the CAP and the exceptions contained in GATT 1994 (Horn and Weiler, 2005). However, again, the Appellate Body focused on ordinary meaning, combined with the limited contextual arguments based on expressio unius and effet utile.

\section{Application of Article $X X(g)$}

There was no doubt that China could seek to defend its quotas under Article XX. China conceded that its export quotas violated Article XI of GATT 1994, so the question was whether they could be excepted under Article XX(g). In order to qualify for an exception under Article XX(g), the relevant measure must (i) relate to the conservation of exhaustible natural resources, (ii) be made effective in conjunction with restrictions on domestic production or consumption, and (iii) satisfy the requirement of the chapeau of Article XX to the effect that it not be applied as arbitrary or unjustifiable discrimination, or a disguised restriction on trade. The burden of proof for each of these parameters is on the respondent. The Panel found that China did not meet this burden of proof as to any of rare earths, tungsten, or molybdenum.

China appealed two sets of intermediate findings in the Panel's analysis of whether China's export quotas on rare earths, tungsten, and molybdenum were justified pursuant to Article XX(g). ${ }^{22}$

- First, China argued that the Panel erred in its interpretation and application of Article XX $(\mathrm{g})$ of the GATT 1994 in finding that China's export quotas on rare

22 China did not appeal the Panel's finding, made on an arguendo basis, that the export duties at issue are not justified by either subparagraph (b) or the chapeau of Article XX of the GATT 1994. Because of the limited scope of China's appeal, even if China had won its appeal, it would still have lost the case. 
earths and tungsten do not 'relate to' conservation within the meaning of Article $\mathrm{XX}(\mathrm{g})$.

- Second, China argued that the Panel erred in finding that China's export quotas on rare earths, tungsten, and molybdenum are not 'made effective in conjunction with' domestic restrictions under Article XX(g).

We first provide an economic analysis of the effects of an export quota and then evaluate the legal arguments in light of the economic analysis.

\subsection{Economic analysis of an export quota}

China argued that its export quota induced foreign consumers to diversify their sources of supply, and that the resulting fall in output was sufficient to establish that its policies 'relate to' conservation. The complainants argued that another effect of the quotas was to increase Chinese consumption of rare earth products, which was not consistent with the argument that the policy was related conservation. We first show that both these claims regarding a Chinese export quota are correct: it will decrease Chinese output and raise Chinese consumption. Therefore, consumption in the rest of the world (ROW) will fall by more than the decline in Chinese output. We then discuss how Chinese consumption taxes, production taxes, and trade policies might be used to achieve a conservation target while satisfying the requirements of Article XX.

The effects of an export quota on a natural resource are illustrated in Figure 1. Panel (a) shows the Chinese market for rare earths and panel (b) shows the market for rare earths in the rest of the world. The $D^{C}\left(p^{c}\right)$ and $S^{C}\left(p^{p}\right)$ curves are the Chinese demand and supply curves, respectively, where $p^{p}$ is the Chinese producer price and $p^{c}$ is the Chinese consumer price. The demand curve in the righthand panel, $D^{R O W}\left(p^{w}\right)$, is the demand for Chinese exports of rare earths in the ROW, which depends on the ROW market price. The supply of exports by China to the ROW is simply the difference between Chinese supply and Chinese demand, and is illustrated by the $X^{C}$ schedule. If China follows a free trade policy and does not impose taxes on domestic consumers and producers, then $p^{c}=p^{D}=p^{w}$. The equilibrium price will be the one at which Chinese export supply equals ROW demand, which is shown by $p_{0}$ in Figure1.

Suppose that China has a goal of reducing extraction of rare earths from the free trade quantity, $Q_{0}^{S}$, to a lower level $\bar{Q}$, in order to conserve rare earths. In order to accomplish this goal, it must reduce the price received by Chinese producers to $p_{1}^{p}$, which is the price at which they will extract the desired quantity $\bar{Q}$. This goal can be accomplished if China imposes an export quota of $\bar{X}$, which makes the export supply curve of China vertical at $\bar{X}$ as illustrated by the dashed line in Figure $1(\mathrm{~b})$. By limiting foreign demand to $\bar{X}$, this export quota has the effect of driving the Chinese price down to $p_{1}^{p}$, which hits the target for reduced output. The reduced supply to market in the rest of the world drives the price paid by consumers up 
Figure 1. Markets for a Chinese resource export good

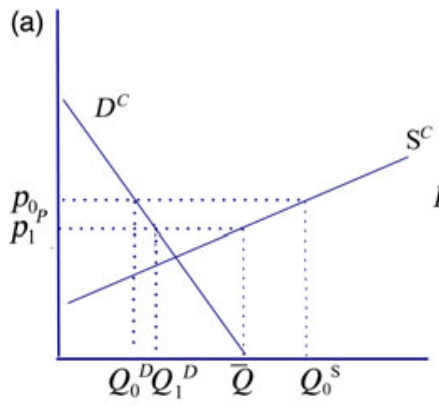

Chinese market

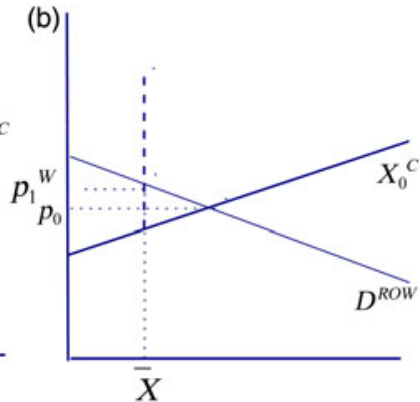

World market

to $p_{1}^{w}$ in Figure $1(\mathrm{~b})$. Note however that since there is no tax on Chinese consumers of the product $D^{C}\left(p^{c}\right)$, their price will be the same as that of Chinese producers. Consumers of rare earths in China will benefit from the drop in price and will increase their consumption to point $Q_{1}^{D}$.

Although the export quota by itself can be used to reduce the extraction of the resource to $\bar{Q}$ by driving up the world price of rare earths and discouraging foreign consumption, it also has the perverse effect of making the price to Chinese consumers of rare earths lower, so that their consumption actually increases. The complainants argued that this indicated that the real intention of the policy was to further the development of the downstream industries in China that used rare earths, and to encourage foreign firms using rare earths to move their production facilities to China.

If the Chinese policy is intended to reduce extraction of rare earths, how should that reduced supply be split between consumers in China and foreign consumers? Economic efficiency suggests a simple solution, which is that the price of Chinese products should be the same for both Chinese and foreign consumers. The reduced output under the conservation policy should be allocated to its most productive uses, which requires consumers in all locations facing the same price. Note that this outcome is also the one that satisfies the requirement of the chapeau that 'such measures are not applied in a manner which would constitute a means of arbitrary or unjustifiable discrimination between countries where the same conditions prevail'.

The question of how the allocation of the reduced output of tungsten and rare earths between Chinese and foreign consumers is affected by Chinese trade and domestic policies can be illustrated using Figure 2. The horizontal axis in Figure 2 has length $\bar{Q}$, which is the target level of Chinese output under the conservation policy from Figure 1. The vertical axis in Figure 2 measures the consumer price. The demand for rare earths by Chinese consumers, $D^{C}$, is measured from left to 
Figure 2. Allocation of $\bar{Q}$ between Chinese and world markets

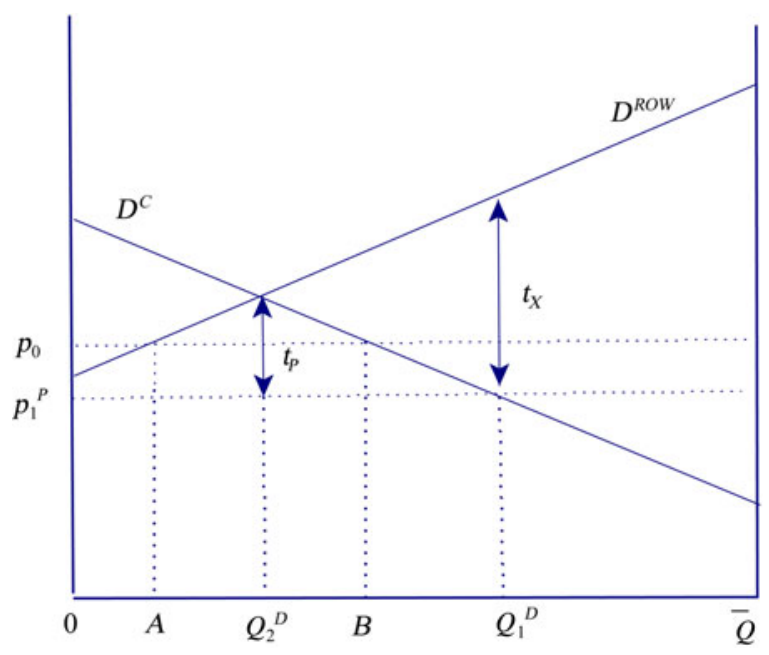

right, and the demand for Chinese rare earths by the rest of the world (ROW), $D^{R O W}$, is measured from right to left. For any point on the horizontal axis, the point above it on $D^{C}$ shows the Chinese price and the point on $D^{R O W}$ shows the foreign price associated with that allocation. Any policy that we consider must result in a price $p_{1}^{p}$ to producers, since that is the price at which they supply the target quantity $\bar{Q}$. The Chinese exports quota of $\bar{X}$ illustrated in Figure 1 results in Chinese consumption of $Q_{1}^{D}$ and a price differential of $t_{X}$ between the price in China and the price in ROW as indicated in Figure 2.

The only allocation of output that results in the same price in both markets is the point at which $D^{C}$ and $D^{R O W}$ intersect, resulting in consumption $Q_{2}^{D}$ in China and exports of $\bar{Q}-Q_{2}^{D}$ for consumption in ROW. The simplest way to achieve this outcome is to impose a tax on Chinese producers of $t_{p}$ as shown in Figure 2. Under a production tax, the reduced supply of the good drives up the price to consumers in all locations by the same amount. As explained in more detail below, the production tax will satisfy the requirement of the chapeau of Article XX, since it does not discriminate between consumers.

Since under an export quota the price to Chinese consumers is equal to the price paid to Chinese producers, a tax on Chinese consumers is required in conjunction with the export tax in order to eliminate the price gap between Chinese and foreign consumers. Referring to Figure 2, the Chinese export quota must be set at $\bar{Q}-Q_{2}^{D}$, and then combined with a tax on Chinese consumers of $t_{p}$. The consumer tax is required to raise the price sufficiently that Chinese consumers choose the quantity $Q_{2}^{D}$. Thus, an export quota can be part of a conservation policy that satisfies the non-discrimination requirement of the chapeau if it is accompanied by a 
consumption tax that eliminates the perverse incentive to consumers. Note however that the conservation policy can always be satisfied without the use of an export policy (whether quota or tax) by the use of a production tax. The use of a production tax avoids the complication of having to match the consumer tax to the price gap introduced by the export quota, and is thus a much more direct approach.

In evaluating the 'related to' requirement of Article XX $(\mathrm{g})$, the Panel (7.4467.448) argued that the Chinese policy was not related to conservation because it was not shown to raise the price to Chinese consumers. Note that the Panel's requirement of evidence that Chinese prices would rise in connection with the 'related to' criterion is also addressed by the 'made effective in conjunction with domestic restrictions' criterion, as well as by the chapeau. However, if the chapeau's requirement of non-discrimination is met, we would expect to see a price rise in China satisfying this 'related to' test, and also satisfaction of the 'made effective in conjunction with' test. Thus, the chapeau addresses the concerns likely to be included in the 'made effective in conjunction with' test, as was the case here. Furthermore, the inclusion of a requirement for domestic price rises in the 'related to' test seems redundant in respect of both the 'made effective in conjunction with' test and the chapeau.

Referring to Figure 2, $p_{0}$ denotes the initial price of rare earths in China before the export tax policy was put in place. Note that any policy that results in Chinese consumption between quantities $\mathrm{A}$ and $\mathrm{B}$ will result in a higher price to consumers in both China and foreign countries when the conservation target is $\bar{Q}$. However, only a policy that achieves Chinese consumption of $Q_{2}^{D}$ will satisfy the requirement of the chapeau.

China argued that it was using production policies (quotas and taxes) to conserve rare earths, and that export quotas were needed as a balancing tool to ensure that foreign consumers conserved natural resources. This argument is clearly flawed, since a production tax or quota in China will reduce supply, which raises the price to consumers in all locations. If an export quota is in place and restricts Chinese exports, it will raise the foreign consumer price above that in China. The way to eliminate that gap is through the use of a tax on Chinese consumers, not through a production tax. Referring to Figure 2, the efficient production tax of $t_{p}$ results in foreign consumption of $\bar{Q}-Q_{2}^{D}$.

Any export quota that is binding and restricts Chinese exports below this level will prevent the efficient outcome from being obtained. An export quota larger than $\bar{Q}-Q_{2}^{D}$ will allow the efficient allocation, but in that case the export quota is not binding. Thus, the only way that a production tax/export tax combination can achieve the desired allocation is one in which the export tax is redundant and can be removed without affecting the policy.

The complainants provided overwhelming empirical evidence that the gap between the Chinese and world price of rare earths increased dramatically following the imposition of Chinese export quotas, indicating that Chinese domestic 
policies failed to offset the discriminatory effect of the export quota. Expert testimony in JE-169 concluded that in the six months following the tightening of the export quota, the export prices of 24 Chinese rare earth products doubled on average relative to the price of the products in the Chinese market. This finding is consistent with the arguments of the complainants that the program's main objective was to favor downstream producers using rare earths in China.

China argued that its export quotas were non-discriminatory because they did not bind in some years for some products. Reductions in world demand for rare earths can result in the quota being non-binding in some periods. This can be seen in Figure 1 by noting that a sufficiently large reduction in $D^{R O W}$ will result in exports less than $\bar{X}$. However, the existence of the quotas means that they can restrain exports in some conditions, and the evidence indicated that they were significant barriers to trade during much of the period.

An economically efficient conservation policy can simply be satisfied by a production tax, which will have a non-discriminatory effect on consumers in different markets. While it is possible to construct a policy package that uses an export quota in conjunction with consumption taxes, such a package would require continual adjustment of policies in response to changes in market conditions to avoid discriminatory outcomes. Any policy intended to conserve natural resources that includes trade policy interventions should be viewed with considerable skepticism.

\subsection{Legal analysis of China's Article XX $(g)$ arguments}

There was no doubt that China could seek to defend its quotas under Article XX. China conceded that its export quotas violated Article XI of GATT 1994, so the question was whether they could be excepted under Article XX $(\mathrm{g})$. China appealed two sets of intermediate findings in the Panel's analysis of whether China's export quotas on rare earths, tungsten, and molybdenum were justified pursuant to Article $\mathrm{XX}(\mathrm{g})$. First, China argued that the Panel erred in its interpretation and application of Article XX $(\mathrm{g})$ of the GATT 1994 in finding that China's export quotas on rare earths and tungsten do not 'relate to' conservation within the meaning of Article $\mathrm{XX}(\mathrm{g})$. Second, China argued that the Panel erred in finding that China's export quotas on rare earths, tungsten, and molybdenum are not 'made effective in conjunction with' domestic restrictions under Article XX $(\mathrm{g})$.

\section{'Relating to'}

As to the 'relating to' prong of the Article $\mathrm{XX}(\mathrm{g})$ test in connection with rare earths and tungsten, China only appealed the Panel's rejection of one of its six arguments: the argument that China's export quota on rare earths and tungsten sends a signal to foreign consumers of rare earth products to diversify their sources of supply and/ or find substitutes for these products that they import from China. If this 'signal' induces foreign consumers to diversify, China's argument goes, then China's export quota can be said to 'relate to' conservation. 
The Appellate Body has moved beyond the requirement, expressed in USGasoline, ${ }^{23}$ that a measure be 'primarily aimed at' conservation in order to satisfy the 'relating to' criterion. ${ }^{24}$ Rather, there must be 'a close and genuine relationship of ends and means' between that measure and the conservation objective. $^{25}$ The Appellate Body stated in this case that 'the text of Article XX(g) does not prescribe a specific analytical framework for assessing whether a measure satisfies the component requirements of that provision'. But it continued that 'all the same, we observe that, in past disputes, the Appellate Body has emphasized the importance of the design and structure of the challenged measure to a proper assessment of whether a measure satisfies the requirements of Article XX $(\mathrm{g})$ '. (para. 5.96)

The Panel based its decision that China's export quotas do not 'relate to' conservation on the Panel's view that, while the quotas would induce conservation on the part of foreign consumers, they would also send a 'perverse signal' of lower prices in the domestic market, inducing reduced conservation by domestic consumers. Consider the Panel's statement on application of Article XX $(\mathrm{g})$ :

[O] ur consideration of the design and architecture of China's export quota on rare earths does not convince us that the export quota is designed in such a way as to ensure that domestic demand is not stimulated by low prices. There does not appear to be any mechanism to ensure that the export quota is set at such a level that, in combination with the extraction and/or production caps, no perverse incentives will be sent to domestic consumers. (para. 7.448)

The Panel seemed to demand that the design and structure reduce domestic consumption, not just overall consumption. As discussed above, the design and structure of an export quota in this context results in a reduction of foreign consumption to an amount greater than the increase in domestic consumption. Thus, in the most basic sense, there is no doubt that China's production quota, considered alone, has the effect of reducing overall output, and thus consumption. Therefore, we must infer that something more than a narrow reduction of output is required in order to 'relate to' conservation. There are two possible additional requirements: first, the Panel and Appellate Body might have required a purer intent, and, second, they might have required greater conservation effect.

Most of the Panel's analysis of the extent to which China's export quota relates to conservation focused on legislative intent, and the Panel found that according to statements of legislative intent China's goal for this legislation was primarily industrial policy (paras. 7.400-7.4006). The Panel found that the non-conservation goals expressed in the legislation prevented an inference of a conservation

23 Appellate Body Report, United States - Standards for Reformulated and Conventional Gasoline, WT/DS2/AB/R, adopted May 1996.

24 Raw Materials Appellate Body Reports, para. 355, citing Shrimp Appellate Body Report, para. 136.

25 Shrimp Appellate Body Report, para. 136. 
purpose, and found that the primary goal of China's export quota was industrial policy (paras. 7.398-7.403). But it is not clear whether the fact that the legislation was primarily aimed at industrial policy is inconsistent with the proposition that it is 'related to' conservation, or that it has a 'close and genuine relationship of means and ends'. Is it possible to have a non-conservation primary goal, and still be 'related to' conservation?

The Panel examined design and structure, finding that while China's measure would cause some reduction of foreign consumption, the 'perverse incentives' expand domestic consumption. As discussed above, this is definitely true in theory and we would expect it to be true in practice. But the Panel never evaluated the magnitude of the foreign reduction, or the magnitude of the effect of the perverse incentives. Our analysis shows that the design and structure reduces output. Note the language of the Panel's statement quoted above: China must ensure that no perverse incentives are sent.

Furthermore, to the extent that the Panel's decision can be understood as based on the disproportionate effects on foreign consumers compared to domestic consumers, incorporating an 'evenhandedness' requirement in the 'related to' test seems less defensible than doing so in connection with the 'made effective in conjunction with' requirement, as discussed below. Evenhandedness is definitely a requirement for economic efficiency, but is it a requirement of this component of Article $\mathrm{XX}(\mathrm{g})$ ? Moreover, the fact that these considerations are specifically covered in the 'made effective in conjunction with' requirement and in the chapeau makes it difficult to infer similar considerations in the 'related to' test.

The Appellate Body simply approved the Panel's reasoning in this context (para. 5.156). The Appellate Body went so far as to state that 'we also consider that the Panel did not, as suggested by China, find that export quotas can send effective conservation signals to foreign users' (para. 5.160). This statement does not seem to comport with what the Panel actually said ('the Panel accepts that export quotas do or at least can send conservation-related signals to foreign users' ${ }^{26}$ ), or with economic theory.

The Appellate Body observed that a focus on 'design and structure' allows the Panel to go beyond the text of the domestic measure, and even beyond ostensible intent, but then it agreed with the Panel, and with prior jurisprudence, that it is not necessary to determine the empirical effects of the measure (para. 5.98). It is true, as the Appellate Body pointed out in US-Gasoline that the empirical determination of effects is fraught with difficulties, not least of which are that no effects might be observed immediately. ${ }^{27}$ China complained that the Panel excluded evidence of effects. Indeed the Panel made the following statement:

26 Rare Earths Panel Reports, para. 7.725. See also ibid., para. 7.443.

27 US-Gasoline Appellate Body Report, p. 20. 
There is therefore no need for the Panel to decide, in quantitative or qualitative terms, precisely what level of contribution a challenged measure has made to the conservation objective. Instead, the Panel looks at the nature of the challenged measures to determine whether, as a matter of design and architecture, they assist, support or further the goal of conservation. ${ }^{28}$

China argued that it was error to exclude evidence of actual effects in cases where a respondent could not successfully show that its measure has the requisite design and structure. ${ }^{29}$ However, the Appellate Body disagreed with China's characterization of the Panel's findings (para 5.108). The Panel merely found that assessment of actual effects was not necessary in this case, not that it was precluded. The Appellate Body stated that 'in any event, where the design and structure of a challenged measure clearly illustrate the absence of a nexus between that measure and the conservation objective, it would be difficult to attribute the evidence of positive effects on conservation to that measure' (para. 5.113). This is the familiar social science precept that without a theory of causation, we cannot attribute causation to correlated events. However, by stating that in this case there was an 'absence of a nexus' with the conservation objective, the Appellate Body seems to ignore the fact that China's measure caused some reduction in output. Where the theory shows no causal role, it is true that there is no reason to look at the facts, but where, as here, the theory shows some causal role, the facts could be relevant.

\section{Made effective in conjunction with domestic restrictions}

China's other claim of error in connection with the Panel's decision regarding Article XX(g) of GATT 1994 had to do with the Panel's statements to the effect that Article XX $(\mathrm{g})$ includes a requirement of 'even-handedness' as between national measures to conserve natural resources that otherwise violate GATT, on the one hand, and restrictions on domestic production or consumption, on the other hand. This concept exceeds the ordinary meaning of Article XX $(\mathrm{g})$, which simply refers to measures 'made effective in conjunction with restrictions on domestic production or consumption'.

The Appellate Body found that evenhandedness is not a separate requirement, but is a shorthand way that has been used to describe the requirement in Article $\mathrm{XX}(\mathrm{g})$ that the measure be made effective in conjunction with domestic restrictions (para. 5124). The Panel did not express with perfect clarity whether it did consider evenhandedness a separate requirement, so the Appellate Body held that 'the Panel erred to the extent that it found that "even-handedness" is a separate requirement that must be fulfilled in addition to the condition that a measure be "made effective in conjunction with restrictions on domestic production or consumption"” (para. 5127). 
Examining the question of whether the Panel erred in its application of this prong, the Appellate Body simply held that the restrictions on domestic production or consumption must be 'real', (para. 5.132) but need not be 'evenly distributed' (para. 5.134).

Here, one might observe that China, along with the Appellate Body, has identified an important avenue for evasion of what one might infer from the text and context was the object and purpose of Article $\mathrm{XX}(\mathrm{g})$ : to ensure authenticity of concern for conservation by requiring that the major burden of the conservation is not imposed on foreign interests. It is arguable that the 'made effective in conjunction with' language has the object and purpose of requiring even-handedness. So this is an example of a textualist interpretation, leaving a possible substantive gap in the WTO object to restrain unjustified protectionism.

The Appellate Body highlighted this concern, noting that 'it would be difficult to conceive of a measure that would impose a significantly more onerous burden on foreign consumers or producers and that could still be shown to satisfy all of the requirements of Article $\mathrm{XX}(\mathrm{g})$ ' (para. 5.134). In any event, this avenue of potential avoidance is not very wide, because the chapeau of Article XX would be likely to deny an exception to measures that constitute a means of arbitrary or unjustifiable discrimination, so long as the chapeau is understood as addressing the measure, and not just the way in which the measure is applied.

Is the price differential between domestic consumers of the resource and those located in the rest of the world a justified price differential from the perspective of conservation? This is a critical question for the evaluation of 'made effective in conjunction with domestic restrictions', since the empirical evidence showed that prices of the relevant materials in China declined relative to world prices after the imposition of the export quota.

If the objective of the policy is to reduce the quantity of the natural resource that is being extracted, then from the point of view of conservation it does not matter whether the consumers of that good reside in the home country or in the rest of the world. However, economic efficiency would argue for allocating this reduced quantity of the resource to its highest value uses, which would require the consumer prices to be equalized between home consumers and those in the rest of the world. The price differential resulting from an export quota could be interpreted as representing 'a means of arbitrary or unjustifiable discrimination between countries where the same conditions prevail' under the chapeau, and would thus not be eligible for protection under Article XX.

A difficulty with the language of Article $\mathrm{XX}(\mathrm{g})$ is the requirement that the trade policy be 'made effective in conjunction with' domestic restrictions does not provide guidance about what forms of domestic policy or what levels of those policies are sufficient to make an export trade policy acceptable. The discussion in Section 4.1 has shown that the use of a consumption tax of equal value to the export trade restriction can achieve economic efficiency. However, the use of a 
consumption tax that is not of equal magnitude to the export trade restriction would not result in efficient resource allocation.

The Appellate Body ruled that the language of Article XX $(\mathrm{g})$ does not contain an 'evenhandedness' requirement. In the absence of further guidance under Article XX (g), the requirement of non-discrimination under the chapeau seems the natural rule for evaluating the extent to which domestic regulations act in conjunction with export policies.

China also challenged the Panel's finding that the 'made effective in conjunction with' requirement is to be evaluated, again, based only on structure and design, and not on actual effects. So, here, although the Appellate Body upheld the Panel's reasoning on the basis that the Panel never stated that it was precluded from examining actual effects, it appears that examination of effects will rarely, if ever, be appropriate. The Appellate Body referred to its earlier response to China's claim regarding 'relating to', stating, puzzlingly, that 'the legal characterization of a measure cannot be contingent upon the occurrence of subsequent events' (para. 5.138).

This language is striking, because the plain language of Article $\mathrm{XX}(\mathrm{g})$ - asking whether a measure relates to conservation of exhaustible natural resources and whether it is made effective in conjunction with domestic restrictions on production or consumption - would ordinarily be understood as asking whether the measure actually conserves natural resources and whether domestic production or consumption is actually restricted. Here, the Appellate Body seems to have read into the text of Article XX $(\mathrm{g})$ words of limitation that are not there.

This counter-textual approach is especially striking when so closely juxtaposed with the Appellate Body and Panel's exaltation of textualism over object and purpose in the context of its analysis of the availability of Article XX to except China's export duties.

\section{Conclusion}

The WTO Dispute Settlement Understanding included a specific reference to the customary international law rules of interpretation, understood to mean the provisions of the Vienna Convention on the Law of Treaties addressing interpretation. While the Appellate Body has taken this instruction to mean that it must focus on text, the relevant language of the Vienna Convention calls also for references to context, object, and purpose, and where those references leave the meaning obscure or absurd, to the circumstances of the treaty's conclusion and its preparatory work.

To be sure, the Appellate Body did utilize context in its interpretation in this case. In connection with its interpretation of the applicability of Article XX, it used an expressio unius approach to find that since there was no specific reference to Article XX in connection with the relevant provisions of the CAP, Article XX did not apply. But the expressio unius canon of interpretation is a passive means 
of interpretation, and can easily be reversed by reference to a more teleological approach to interpretation, as would be required by a reference to object and purpose in this case. Indeed, if we focus on preambular language in the WTO Charter calling for a balance between environmental protection and trade, and the context of Article XX qualifications available for comparable obligations of every other state (not to mention the fact that most other states are permitted to apply export duties without restriction), it is an abstemious textualism indeed that declines to extend Article XX exceptions to China's export duties. ${ }^{30}$

So, the Appellate Body's approach to textualism is not required by the instructions contained in the WTO treaty, and to the extent that it excludes object and purpose, it is not permitted (Qin, 2014). It is understandable that the Appellate Body would expect that textualism insulates it from criticism, and deflects responsibility to the Member States. Thus, perhaps textualism was the right strategy for the early Appellate Body. As Hudec mentioned in the context of the Appellate Body's approach to WTO legal rules restricting domestic regulation, 'recognizing (its) very exposed position, the Appellate Body may well have concluded that the safest refuge from political criticism was to stay as close as possible to the shelter of the legal texts accepted by governments' (Hudec, 1998). But is it still normatively attractive for a judge to leave the text as it stands, declining to amplify, limit, or correct the text?

The WTO Agreement may be understood as a state-contingent contract containing obligations and exceptions, each dependent on findings of particular facts. The exceptions contained in Article XX of GATT may be understood as designed to provide a mechanism for relaxing WTO obligations where specified reasons apply and specified conditions are met. This serves to preserve WTO obligations, while ensuring that compliance with these obligations is not excessively costly in terms of other values, such as conservation of exhaustible natural resources.

The Appellate Body's approach to interpretation, focused as it is on text and a narrow approach to context, as evidenced in Rare Earths, may emphasize these interpretive elements under Article 31 of the VCLT excessively, providing insufficient emphasis on broader context, object, and purpose. The result in this case is to provide a rigid obligation with respect to China's export duties on rare earths under Article 11.3 of the CAP, without benefit of the conditional exceptions under Article XX.

Export quotas will not generally be economically efficient mechanisms for conservation of exhaustible natural resources. However, this does not necessarily mean that they cannot, under any circumstances, 'relate to' conservation within the meaning of Article XX(g). While China's export quota on rare earths could not meet the requirements of the Article XX chapeau, the Appellate Body

30 For a trenchant criticism of this limited approach to interpretation in a similar context, see Irwin and Weiler (2008). 
confirmed the Panel's approach to Article $\mathrm{XX}(\mathrm{g})$ in a way that makes it unclear how this defense will operate in the future.

First, while the Appellate Body confirmed the Panel's finding that the structure and design of China's quota does not 'relate to' conservation, it did not deal with the fact that the structure and design of China's measure, in economic terms, will reduce output. While the narrow reduction of output may be insufficient to 'relate to' conservation, neither the Panel nor the Appellate Body explains how China's measure failed to meet the test. Perhaps the problem was that China's measure was primarily addressed to industrial policy purposes. Perhaps the problem was that China's measure failed to provide sufficient benefits in terms of conservation. If the problem was the latter, it would have been appropriate for the Panel to allow China to present evidence of the extent of conservation effects.

Second, while the Appellate Body found that the 'made effective in conjunction with domestic restrictions' prong of the Article $\mathrm{XX}(\mathrm{g})$ test does not require evenhandedness, it did not provide guidance to future panels as to how to compare the magnitude of domestic restrictions to the magnitude of measures sought to be justified under Article XX(g). The Appellate Body also accepted the Panel's determination not to examine empirical evidence offered by China of the conservation effects of its domestic measures compared to the conservation effects of its export quota.

\section{References}

Bronckers, M. and K. E. Maskus (2014), 'China-Raw Materials: A Controversial Step Towards Evenhanded Exploitation of Natural Resources', World Trade Review, 13(2): 398.

Horn, H. and J. H. H. Weiler (2005), 'European Communities-Trade Description of Sardines: Textualism and its Discontents', in H. Horn and P. Mavroidis (eds.), WTO Case Law of 2002, Cambridge, Cambridge University Press.

Hudec, R. E. (1998), 'GATT/WTO Constraints on National Regulation: Requiem for An "Aim and Effects” Test', International Lawyer, 32: 619.

Irwin, D. A. and J. H. H. Weiler (2008), 'Measures Affecting the Cross-Border Supply of Gambling and Betting Services (DS285)', World Trade Review, 7(1): 71-113.

Morrison, W. M. and R. Tang (2012), China's Rare Earth Industry and Export Regime: Economic and Trade Implications for the United States, Congressional Research Service.

Qin, J. Y. (2012), 'The Predicament of China's 'WTO-Plus' Obligation to Eliminate Export Duties: A Commentary on the China-Raw Materials Case', Chinese Journal of International Law, 11: 237-246.

- (2014), 'Judicial Authority in WTO Law: A Commentary on the Appellate Body's Decision in ChinaRare Earths', Chinese Journal of International Law, 13.

Trachtman, J. P. (2013), The Tools of Argument: How the Best Lawyers Think, Argue, and Win, CreateSpace Independent Publishing Platform, pp. 97-100.

Van Damme, I. (2009), Treaty Interpretation by the WTO Appellate Body, Oxford: Oxford University Press, pp. 218-219.

Williamson, O. (1985), The Economic Institutions of Capitalism: Firms, Markets, Relational Contracting, New York: Free Press. 